\title{
Yaşlanan Alman Nüfusu ve Artan Göçmen İhtiyacı Arasındaki îlişkinin Değerlendirilmesi: Yükselen Irkçılık, Yabancı Düşmanlığı ve Ayrımcılık
}

\author{
Faik Tanrıkulu'+
}

Öz

2015 yılındaki mülteci akını ile birlikte Almanya'da göç tartı̧̧maları tekrar siyasetin ana gündem konularından biri olmaya başlamıştır. Bu süreçte 2017 yılında yapılan genel seçimlerde aşırı sağ partiler rekor seviyede oy almış, buna paralel merkez partiler de seçim öncesinde yabancı karşıtlığı söylem ve vaatlerde bulunarak bu olumsuz havaya ayak uydurmuştur. Peki gerçekten Almanya bir göç ülkesi mi veya rasyonel olarak düşünüldüğünde Almanya'nın göçmen almaya ihtiyacı var mı? Bu ve benzer soruların yanısıra bir taraftan yaşlanan nüfus diğer taraftan vasıflı/vasıfsız eleman ihtiyacının giderek arttğı gerçeği bazı politikacılar ve bürokratlar tarafiından sıkça dillendirilmektedir. Bu çalışma muhtemel senaryolar ışığında Alman nüfusunun gelecekte nasıl şekilleneceğini ve Almanya'nın göç ülkesi olup olmayacağını nicel araştırmalarla ortaya çıkarmaktadır. Yaşlanan nüfusla birlikte her yıl genç nüfus ihtiyacı artan Almanya'da yetişmiş göçmenler ülkeyi terk etmektedir. Bir taraftan göçmenler sürekli olumsuz haberlerle gündem olurken, diğer taraftan göçmenlerin ülkeye olan katkıları önemsiz gösterilmekte ve Almanya'nın bir göç ülkesi olduğu unutulmaktadır. Bu çalışma Almanya'daki demografik dönüşüm bağlamında artan göçmen ihtiyacını irdeleyecektir. Buna paralel olarak da yabancı düşmanlığı, yükselen ırkçıık ve şiddet eğilimlerinin son senelerde artmasının olumsuz neticelerinin gelecekte ne tür sonuçlar doğuracağı incelenecektir.

\section{Anahtar Kelimeler}

Yaşlanan nüfus • Göç ve mülteci • Demografik dönüşüm • Uyum • İş piyasası • Yabancı düşmanlığı, Irkçılık yabancı düşmanlığı ve ayrımcılık. Sosyal Siyaset Konferans/arı Dergisi, 75, 93-122. http://dx.doi.org/10.26650/jspc.2018.75.0010 


\title{
Assessment of the Relation Between the Aging German Population and Increasing Immigrant Needs: Rising Racism, Xenophobia, and Discrimination
}

\author{
Faik Tanrıkulu'
}

\begin{abstract}
Discussion about migration became one of the main subjects on the political agenda in Germany, especially in 2015 when the country experienced an intense flux of immigrants. There was a general election in 2017, and far-right parties gained votes at a high level. During the election campaign, central parties took advantage of xenophobic discourse and commitment, and as such they were in compliance with the political atmosphere. Is Germany indeed an immigrant country or does Germany need to accept immigrants from a rational perspective? The reality of having an aging population and the growing scarcity of qualified/ unqualified staffs are often emphasized by some politicians and bureaucrats. By considering a possible scenario and using quantitative research methods, this study reveals how the German population would be considered in the future and whether Germany is an immigrant country. The increase in the aging population triggered the need for a young population because well-trained young immigrants were leaving the country. Unfavorable news about immigrants is generally at the top of the country's agenda, and their contribution to the country is often downplayed. Germany as a country of immigrants has completely been forgotten. This study examines the increasing demand for immigrants in context of demographic transformation as well as corresponding to xenophobia, escalation of racism, and a tendency to commit violence, which have been on the rise in the last several years. The study also discusses possible results.
\end{abstract}

\section{Keywords}

Aging population $\bullet$ Migration and refugees $\bullet$ Demographic transformation $\bullet$ Integration $\bullet$ Labor market $\bullet$ Xenophobia

1 Coresponding author: Faik Tanrıkulu (Dr. Öğr. Üyesi), Medipol University, Faculty of Humanities and Social Sciences, Department of Political Sciences and Administrative Science Istanbul, Turkey. Email: ftanrikulu@medipol.edu.tr

To cite this article: Tanrıkulu, F. (2018). Assessment of the relation between the aging german population and increasing immigrant needs: Rising racism, xenophobia, and discrimination. Sosyal Siyaset Konferansları Dergisi, 75, 93-122. http://dx.doi.org/10.26650/jspc.2018.75.0010 


\section{Extended Summary}

It is evident from the previous century that Europe has undergone statistical and structural changes in terms of low birth rate and eventual rise of life expectancy. Based on modernization and economic growth, there is a significant impairment in the population's structure. This demographic evolution will influence the functioning of the social security system, including households, labor, and public and private infrastructure (the closure of schools, scarcity of registered students).

In the wake of World War II, guest workers played a significant role in shaping the demographic evolution in Germany. Those who migrated to Germany as guest workers (Gastarbeiter) became more permanent as their families came to Germany when family unification was allowed. The German population gradually became diversified. Moreover, Max Frisch, an author about World War II and its aftermath, said "we invited labour but plenty of people came" (man hat Arbeitskraefte gerufen und es kommen menschen), which is the epitome statement about how immigrants were perceived in Germany.

Although Germany considered the first group of immigrant workers as temporary guests by definition, after the 1990s, many issues relevant to immigrants like migration policies, citizenship, and adaptation of foreigners were on the political agenda. During this process, Germany avoided considering itself a "migrant country." In recent years, $\mathrm{CDU}$, the coalition partner, occasionally remained indecisive on the subject of political settlement toward immigrants because the electorate reacts negatively to this subject while economic experts support it. At the same time, the Christian Democratic Union Parties that do not want a widespread support shift to a racist party also have difficulties accepting that Germany has become an immigrant country. On the one hand, they resist the actualization of legal arrangements and policies that immigrants and refugees require; on the other hand, they are pushed to address the labor demands of the economy like the chamber of industry and trade. Projections suggest that to sustain economic development, there is a need for half a million immigrants each year because of the aging population, and it also needs to implement policies with the aim of retaining the born-and-raised immigrants in the country.

Germany was unable to attract immigrants to the country even though multiple solutions like birth incentive and blue card application were made available. While discriminative attitudes toward immigrants discourage qualified personnel's intention to come to Germany, educated immigrants living in the country also prefer to leave the country. This dilemma is a serious threat to Germany as the country's future depends on the continuity of immigration flow. At the end of 2016, the population was composed of 9 million immigrants with different nationalities and citizenship 
backgrounds, and 9.6 million immigrants with German citizenship, which amounts to 18.6 million immigrants or 22.5 percent of the total population. Individuals with immigrant backgrounds have become permanent, and their participation in society cannot be ignored (Bevölkerung mit Migrationshintergrund, 2018).

Changes in the rates of birth and death are an unavoidable reality that illustrate how Germany's age and population structures are transforming. Studies by academics and public institutes specify that within 20 years, the German population will not increase without receiving additional immigrants, and if this happens, the population will decrease from 81 million to 66 million by 2050 . Based on an examination of the last 20 years, approximately 475,000 immigrants whose education was completed in Germany migrated to other countries. In Germany, it is considered state policy to both bring in qualified personnel from abroad and keep educated immigrants in the country. The German state provided a subsidy for this purpose, and since 2000, families have regularly been given substantial support with the aim of raising the birth rate and family protection. However, no increase in the birth rate is evident. The rise of far-right parties and the central parties using xenophobia to boost support, especially in election periods, makes immigrants feel anxious. Although the Berlin government intended to meet the labor deficit from EU countries, no result has occurred.

Actual political discussion was once determined by issues of immigrants, and it is now determined by refugees. These debates have paved the way for investigation into whether Germany is an immigrant country or not. While German Chancellor Angela Merkel admitted "Germany's being migration country," politicians and bureaucrats slammed Merkel for her discourse on migration. Compulsory migration or migration on a voluntary basis (qualified or non-qualified) would seemingly maintain cultural diversity and multi-culturalism in Germany. In spite of this, Germany is decreasing its cultural richness and integration, and it systematically persists in xenophobia against immigrants. Economic requirements necessitate the structure of a multicultural society. However, states are oscillating between forcing the nature of the nation state and denying multi-culturalism on the basis of national sovereignty. As a result of this, for social and economic adaptation, individuals with immigrant backgrounds must benefit from equal rights by being supported with good vocation and educational methods. If Germany aims to increase the population with incentive policies, the country must avoid racist rhetoric and politics, which could possibly rise to the surface if the desired achievement is not attained. 


\section{Yaşlanan Alman Nüfusu ve Artan Göçmen İhtiyacı Arasındaki İlişkinin Değerlendirilmesi: Yükselen Irkçılık, Yabancı Düşmanlığı ve Ayrımcılık}

Almanya ikinci dünya savaşı sonunda iktisadi büyüme trendi ve sanayileşmeyle birlikte ciddi iş gücüne ihtiyaç duymuştur. Devletin geçici çözüm olarak gördügü misafir işçiler zaman içerisinde aileleri ve yakınlarını almasıyla birlikte kalıcı olmaya başlamıştır. Hatta ünlü yazar Max Frisch bu yeni durumu " Biz işgücü çağırdık, ama insanlar geldi" ş̧eklinde yorumlamıştır (Wir riefen Arbeitskräfte und es kamen Menschen, 2018). Bu bakış 1990'a kadar devlet politikalarına da yansımıştır. 90'lı yıllardan sonra göçmenleri ilgilendiren hususlar gündeme gelmiş, vatandaşl1k, göçmenlerin uyumu ve göç politikaları karar vericiler tarafindan ele alınmıştır. Bu süreçte Alman devleti kendisini uzun süre "'göç ülkesi" olarak görmek istememiştir.

Koalisyon ortağı CDU (Hristiyan Demokrat Partisi) bir taraftan seçmen tabanın tepkisi, diğer taraftan iktisadi çevrelerden gelen destek arasında göçmen politikalarını belirleme konusunda zaman zaman kararsız kalmaktadır. Gelecek projeksiyonlar iktisadi büyümenin sürdürülebilmesi için yaşlanan Alman nüfusuna karşı her yıl yarım milyon göçmenin gelmesi ve Almanya'da doğup büyüyen göçmenleri ülkede tutabilecek politikalar geliştirilmesi gerektiğini bildirmektedir. Bu bağlamda dönemsel olarak farklı uygulamalar ve teşvikler (Mavi kart, doğum destekleri) denendiyse de istenilen başarıya ulaşılamamıştır. Göçmenlere yönelik yaygın ayrımcı tutumlar hem yurtdışından gelecek elemanlara mâni olurken, hem de ülkede bulunan göçmenlerin ülkeyi terk etmesine neden olmaktadır. Hali hazırda nüfusunun \%20'si göçmen kökenli bireylerden oluşan Almanya göçmenlere yönelik uyum adı altında yabancı düşmanlığını sürdürme eğilimindedir. Ancak ekonomik ihtiyaçlar ve demografik yapı çokkültürlü toplumu gerekli kılmaktadır.

Çalışma hızla yaşlanan Alman nüfusunda yaşanan değiş̧imin öncesi, bugünü ve geleceğini resmi istatistikler, raporlar ve siyasi beyanatlarla açıklamaktadır. Nüfusun giderek yaşlandığ 1 ülkenin ekonomisine baskı uyguladığg açık bir şekilde ortaya çıkmaktadır. Sürdürebilir bir gelişme için ülkenin sürekli işgücüne ihtiyaç duyduğunu araştırmalar net bir şekilde göstermektedir. Emeklilik yaşının yükselmesi, doğum teşvik oranlarının artırılması gibi çözümler bugüne kadar sonuç vermemiştir. Araştırma göçmenlerin maruz kald1ğ1 ayrımcı işlemlere, 1rkçılık ve yabancı düşmanlığı gibi yükselişe geçen mu- 
ameleleri farklı kaynaklardan ortaya çıkarmaktadır. Aynı şekilde göçmenlerin ülkeye sağladığı katkılar verilerle ve resmî açıklamalarla desteklenmektedir. $\mathrm{Bu}$ bilgiler 1şığında çalışma gelecekte Alman nüfusunun nasıl şekilleneceği ve göç politikaların nasıl olması gerektiğini hususunda öneriler sunmaktadır.

\section{Kavramsal Çerçeve}

\section{Göç}

Küreselleşmeyle birlikte iç savaş, siyasi ve ekonomik istikrarsızlıklar göç hareketlerini hızlandırmaktadır. Göç sosyoloji, ekonomi ve siyaset gibi farklı disiplinleri de kapsayan geniş çalışma sahasıdır. Kitlesel göçlerin, iç karışıkların ve siyasi istikrarsızlıkların sadece komşu ülkeleri değil, bölge ülkelerinin tamamını etkilediği görülmüştür. Aynı şekilde göç birçok ülkede siyasi, ekonomik ve bölgesel politika paradigmasını da değiştirebilmektedir. $\mathrm{Bu}$ nedenle göç meselesi çok taraflı ve farklı perspektiften ele alınması gereken konulardan biridir. Göçle ilgili farklı tanımlar ve yorumlar yapılmaktadır. Illian (2011, s.17) göçü bir veya birkaç kişinin yaşamlarını sürdükleri yerleri uzun süre terketmesi olarak ifade etmektedir. Ayrıca göç edenlerin sadece hayatlarını değiştirmiş olmadığını, aynı zamanda gittikleri ülkenin yaşam alışkanlıklarını da değiştirdiğini belirtmektedir. Albert 'Göçün sadece mekânsal değişim olarak değerlendirilemiyeceğini, aynı zamanda göç edilen ülkenin sosyal hayatını da dönüş̧ürme potansiyeline sahip olduğunu”" (Albrecht, 1972, s.23) söylemektedir. Çeşitli örneklere baktığımızda Avrupa ülkelerinde göçmenlerin yoğun yaşadıkları şehirlerde ülkelerindeki hayat alışkanlıklarını ve kültürlerini göç ettikleri ülkelere taşıdıkları ve yerel toplumu etkiledikleri görülmektedir.

Göç nedenleri zorunlu ve gönüllü göç olarak iki ana grupta ele alınmaktadır. Gönüllü göç bireyin kendi isteğiyle ülkesini terk ederek yurtdışında yaşamaya başladığı süreçtir. Zorunlu göç ise isteği dışında savaş, siyasi ve ekonomik krizler gibi sebeplerden dolayı ülkesini terk etmek zorunda kalan kimseler için kullanılan kavramdır (Illian, 2003, s.20).

Eisenstadt "Göçmenlerin başka ülkeye göç ettikleri süreçte uyum sağlayabilmeleri için yeni rol ve görevler üstlenerek kendi değerlerini yeniden tanımlama ihtiyacı hissetmek zorunda olduklarını" ileri sürmektedir. Yabancı top- 
lumda göçmenlerin kendi ülkesinden farklı olarak yeni sosyal hayat ve statü arama çabasında olacaklarından ve ülkeye uyum sağlamanın zorluklarından bahsetmektedir. Buna karşı göçmenlerin göç ettikleri ülkenin hayat tarzlarına ve kültürüne uymalarını beklediğini ifade etmektedir (Eisenstadt, 1953, s.20).

Göç hareketleri aşağıda belirtilen 5 farklı kategoride değerlendirilmektedir.

- Süresiz göç: Yüksek kalifiye sahibi kimseler, aile birleşimi

- Geçici süreli göç: Misafir işçi veya mevsimlik işçi vb.

- İstihdam süresi belirli olan işler kapsamında göç: İstisna akdi veya mevsimlik işler

- Düzensiz göç ve kayıt dışı göç

- Mülteciler

Gelişmiş ülkelerde iş piyasası, istikrarlı ekonomi, iyi hayat şartları göçmenlere çekici gelmektedir. İktisadi nedenlerin dışında iç savaş, doğal afetler, anti-demokratik yaklaşımlar insanları kendi ülkelerini terketmek zorunda b1rakabilmektedir. Bunlar dişında küreselleşmenin artmasıyla birlikte ekonomi piyasası ve iş piyasa kültürü de göç akınına yol açmaktadır (Münz, Seifert e Ulrich, 1997, s.16).

\section{Zincirleme göç}

Göç eden insanlar doğal olarak bulundukları ülkelerde hayata tutunmakta başlangıçta zorlanmaktadır. Dil bilmeme ve farklı kültürlerle birarada yaşama süreci ilk etapta göçmenleri sosyal hayattan uzak tutmaktadır. Göçmenler göç ettikleri ülkede süreç içerisinde kendilerinin rahat iletişim sağlayacağ 1 ve ülke hasretini giderecekleri insanlarla birarada yaşama arzusu içerisinde olmaktadır. Aile üyelerini ve tanıdıklarını bulundukları ülkelere gelmeye teşvik etmektedir. Göçmenler hem iş arama hem de ev bulma hususunda yakınlarına kolaylık sağlamaktadır. Bir nevi kendi köyünü ve çevresini yurtdışında yaşamaktadır. Buna benzer olanaklar ülkelerde daha uzun kalmalarını sağlayıp ve ülkelerine dönmekten vazgeçirebilmektedir (Han, 2000,14). Bilhassa Türkiye'den Avrupa'ya göç eden göçmenlerde zincirleme göç bariz şekilde görülmektedir. Türkiye'den aynı köy ya da şehirden giden göçmenler yakın yerlerde ikamet etmeyi tercih etmektedir. 
Bunun yanısıra göç bir çok faktöre bağlı olarak değişmektedir. Duygusal toplumlarda yurtdışında tanıdık birilerinin olması göç etme sürecini ve kararını hızlandırmaktadır. İnsanlar sosyal statülerini düzeltmek ve kariyerlerini yurtdışında

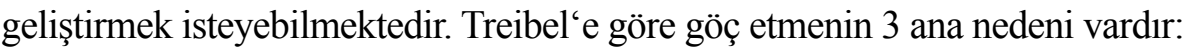

- Göçün fiziksel nedenleri ve ailelerin güvende olmaması

- Siyasi ve ideolojik olaylar

- İdeallerinin gerçekleştirememe düşüncesi (Treibel, 2003, s.43)

\section{İşgücü}

Göç kavramı daha çok istem dışı gelen insan topluluğu için kullanılmaktadır. Kendi ülkelerinde yaşadıkları güvenlik riski, siyasi ve kültürel ya da dini sebeplerden dolayı ülkesinden uzaklaşmak isteyenlere verilen bir isimdir. İşgücünde ise insanlar göç ettikleri ülkelerde daha iyi hayat şartları sağlama veya ekonomik gelirini güvence altına alma arzusu içerisinde göç etmektedir. (Oswald, 2007, s.76).

\section{Kuramsal Yaklaşımlar}

\section{Çokkültürlü Toplum Tartışmaları}

Almanya'nın çokkültürlü mü yoksa ulus devletimi olup olmadığı sıkça tartışılan konular arasındadır. Zaman zaman siyasetçiler çokkültürlü toplum olduklarını reddederken, bazı politikacılar ise artık Almanya'nın bir göç ülkesi olduğunu söylemektedir. Esasında bu kafa karışıklığu göç politikalarına da yansımaktadır. Çokkültürlülük farklı etnik ve kültür gruplarıyla barış içerisinde birarada yaşama olarak tanımlanmaktadır. Kuram göçmenlere karşı daha açık, özgür, farklı fikirleri, dini çeşitliliği, diğer etnik ve dillerin toplumda kabul görmesini ve devlet tarafından hakların güvence altına alınmasını savunmaktadır. AB ülkelerinde göçmen nüfusun artması ile birlikte "multiculturalism" (çokkültürlülük) terimi sıkça kullanılmaktadır (Schubert ve Klein, 2011, s.27). Jaggi, '’Çokkültürlülüğü herhangi bir değer veya ideoloji olarak değil, daha çok bu dönemde gerçeğin değişimi olarak değerlendirirken, artık tek kültürlü bir toplumun hemen hemen olmadığını ve gelecekte bu dönüşümden birçok devletin etkileneceğini" savunmuştur. Bu iddiasını ileri sürerken 1971 yılında dünya çapında sadece 12 devletin etnik bakımdan homojen oldu- 
ğunu örnek olarak göstermektedir. O yıllardan bugünlere artan nüfus hareketliliği de göz önüne alındığında, günümüzde çok etnikli toplumu yansıtmayan bir devletin olamayacağını öngörmektedir (Jaggi, 1996, s.427). Bu nedenle çokkültürlü devletlerin göçmenleri dezavantajlı grup olarak değerlendirilmesi gerektiğini ve pozitif ayrımcılık yapılmasını önermektedir (vergi avantajlarının sunulması, dil kurslarına maddi desteklerde, kamu yardımları veya iş alımlarında göçmenlere öncelik verilmesi gibi). Aynı şekilde kuram göçmenlerin dini ve kültürel kimliklerini koruyarak da ülkenin kalkınmasına fayda sağlayabileceğini ifade etmektedir (Wieviorka, 2003, s.98).

Özellikle Almanya'da artan etnik çeşitliliğin önemli miktarının AB dışı ülkelerden oluşması çokkültürlü toplumun temelini teşkil etmektedir. Kültürel ve dini olarak farklı bir hayat tarzına sahip olan Alman toplumu; kültürel, dini ve etnik çeşitlilikle yaşamak durumundadır. Göçmenlerin kabul edildikleri toplumlarda o toplumun kültür ve kurumlarınca asimile edilmesine yönelik politikalar göçmenlerin kolektif kimliklerini ve uyumlarını zorlaştırmaktadır. Uzmanlar hem göçmenlerin hem de Alman toplumu temsilcilerinin çokkültürlülüğü kabullenen bir yöne kayması gerektiğini söylemektedir.

Göç ve mülteci akınıyla birlikte 90‘lı yıllardan farklı olarak bugün artık Alman toplumunda "göç milleti" bilinci daha çok artmıştır. Aşırı sağ hareketler Almanya'nın artık göç ülkesi olduğunu kabul etmeseler de göçmenlerin ve mültecilerin gelmesiyle toplum çokkültürlü yapıya dönüşmüştür.

\section{Modernleşme ve Gelişme Kuramı}

Dünya'da artan göç hareketlerine paralel farklı göç kuramları da aynı şekilde geliştirilmiştir. Sosyal bilimlerde işgücü ve göç konularını içeren yaygın kuramlar modernleşme/kalkınma ve merkez-çevre olarak kullanılmaktadır. Push ve Pull modelleri ise en çok tanınan ve kullanılan metodlardan birisidir. Daha çok göçün avantajlı ve dezavantajlı durumları incelenerek göç etmenin ne derece anlamlı olup olmadığı araştırılmaktadır. Ayrıca göçe sebep olan koşullar incelenmektedir (Oswald ,2007, s.73). Kuram göç akımlarını ülkelerdeki ekonomik istikrarın bozulmasını Push ve Pull faktörleri ile ilişkilendirmektedir. İşsizlik, siyasi istikrarsızlık ve ekonomik durgunluk gibi nedenler yabancılar için "Push" itici faktör olarak yorumlanmaktadır. Diğer taraftan, göçmenlerin gelişmiş ülkelere gitmeyi tercih etmesi çekici “Pull" olarak değerlendirilmektedir. 
Kuram göç eden kimselerin çalıştıkları ülkelerde mesleki ve teknik becerilerini geliştireceklerini, maddi gelir sağlayarak kendi ülkesinin ekonomisine katkı sağladığını ve bulundukları ülkelerde birer kültür elçisi olarak bulunduğundan bahsetmektedir. Aynı şekilde göçmenlerin gittikleri ülkedeki kültürel ve sosyal değişime katkıda bulunduklarını ileri sürmektedir (Şahin, 2001, s.57).

\section{Merkez- Çevre Kuramı}

Bu kuram daha çok genellikle göçün olumsuz yönlerine odaklanmaktadır. Göçün modernleşme ve kalkınmaya faydasının olmadığı, tam aksine gelişmekte olan ülkelerin sosyo-ekonomik kalkınmasına olumsuz yönde etkilediğini iddia etmektedir. Diğer bir deyişle, göç edenlerin geri döndüklerinde tükenmiş, sağl1ksız ve yaşlı olarak geldiklerini bu nedenle ülke ekonomisine katkıda bulunamayacaklarını belirtmektedir. Aynı şekilde, göçmenler bulundukları ülkelerde daha çok tehlikeli ve vasıfsız işlerde çalışmaktadır. Meslek eğitimi ve dil bilgisi konusunda geri kalmaktadır. Çalıştıkları koşullar gözönüne alındığında dil bilme ihtiyacı da hissetmemişlerdir. Bu sebeple göç ettikleri ülkelerin yaşam standartları, bilgi ve normlardan yeterince faydalanamadıklarını ileri sürmektedir. Bundan dolayı çalışılan ülkenin iktisadi yapısınıda olumsuz yönde etkilediği görüşünü savunmaktadır (Martin, 1991, s.51). Başka deyişle, genel olarak göçmenlerin kalifiye olmayan kimselerin olduğunu ve meslek-teknik bilgilerinin yeterli seviye olmadığını düşünerek göç ettikleri ülkelere fayda sağlamadığı düşüncesindedir.

\section{Almanya'nın Göç Politikası}

\section{İkinci Dünya Savaşı Sonrası}

İkinci dünya savaşından önce 1,3 milyon yabancı AB ülkelerinde yaşamıştır. İkinci dünya savaşı sırasında göçmenler, savaşın etkisiyle küçülen Alman ekonomisinden dolayı başka ülkere göç etmişlerdir. Takriben 1944 yılında 7,8 milyon hayatta kalan savaş tutuklusu yabancı, kendi ülkelerine veya okyanus ötesi ülkelere göç etmiştir (Bade,1992, s.35).

1950 yılından sonra, Almanya'nın ekonomik mucize olarak adlandırıldığı dönemde iş gücüne duyulan ihtiyaç artmıştır. Başta Güney Avrupa ülkelerinden bu açık kapatılmak istenmiş olsa da kısa dönemde olumlu sonuç vermemiştir. Bu nedenle diğer ülkeler arasında yabancı iş gücü transferi için antlaşmalar yapılııştır. 
Ancak devlet artan iş gücüne karşı işçilerin kısa süre çalışıp ülkelerine döneceğini varsaymıştır. Hatta o dönem içerisinde yapılan resmi yazışmalarda "yabancı ülkeden işçi“" ve "misafir işçi“" gibi tanımlamalar kullanılmıştır. Esasen "misafir işçi " kavramı daha yaygın kullanılırken endüstri üretiminde ise genellikle yabancılar"çalışan" olarak ifade edilmiştir. Genel olarak göçmenlerin çalıştıkları işler düşük ücretli ve vasıfsız işler olmuştur (Bade, 1992, s.395). 50'li yıllarda 72 bin olan yabancı iş gücü on yıl sonra 329 bine yükselmiştir.

1964 yılına gelindiğinde Almanya'nın toplam nüfusunun 2,1 milyonu yabancılardan oluşurken bu sayı 1973 yılında 2,6 milyona ulaşmıştır. Türkiye başta olmak üzere iş göçü, eski Yugoslavya ve İtalya gibi ülkelerden gelmiştir (Münz, Ulrich ve Seifert,1997, s.36-37). İlk gelen göçmen işçiler için, çalışma ve ikamet izni bir sene olarak belirlenmişti, ancak sayının artmasıyla Federal hükümet 1971 yılında ikamet izinlerini yeniden düzenlemiştir. Bu süreçten sonra Almanya'da bulunan göçmenler bir yıldan fazla kalma hakkı elde etmiş ve aile mensuplarını getirmeye başlamıştır (Münz, Ulrich ve Seifert, 1997, s.40). Doğu Almanya 'da da benzer durumlar yaşanmıştı, ancak yapılan iş gücü anlaşması daha çok Orta Avrupa, Küba ve Vietnam gibi ülkeleri kapsamıştır. Fakat Batı Almanya ile kıyaslandığında ülkede kalma şartları ağır koşullara bağlıydı, dolayısıyla hemen hemen bir çoğu iş süresi bittikten sonra kendi ülkelerine dönüş yapmak zorunda kalmıştır. Gerek Yugoslavya'daki karışıklıklar gerekse Türkiye ve bölgedeki diğer ülkelerde yaşanan ekonomik krizler ve Almanya'nın birleşmesiyle iş göçü sayısı hızla artmıştır. Bir kısmı sezonluk işçi olarak ya da mesleki kalifikasyonunu geliştirmek için Almanya'ya göç etmeyi tercih etmiştir. Sayı olarak incelendiğinde 1954- 1995 yılları arasında 22,7 milyon yabancı Almanya'ya yerleşmiş, buna karşın 16,2 milyon göçmen ülkeyi terk etmiştir. (Münz, Ulrich ve Seifert,1997,42-45). Tabiatıyla iç politikada mülteci başvurusunda artışın devam etmesi ve yabancı nüfusun çoğalması ile birlikte göç siyasi partiler tarafından ana gündem konusu olmaya başlamıştır. $O$ yıllarda işsizlik ve yabancılara karşı tepkilerin artması neticesinde 1981'de SDP/FDP hükümetinin yabancıların geri dönüşlerine maddi destek kararı vermesi sonucunda göçmenlerin birçoğu teşvik kapsamında ülkelerine dönmüştür (Von der "Gastarbeiter"Anwerbung zum Zuwanderungsgesetz für politische Bildung, 2017). Akabinde 1993 yılında Federal Hükümet yabancı iş gücünü sonlandırmak istemiş ve bu yönde politikalar takip etmiştir (Von der „Gastarbeiter“-Anwerbung zum Zuwanderungsgesetz für politische Bildung,2017). 


\section{Göç Politikalarında Değişim}

1990'lı yıllara gelindiğinde mülteci, yabancı ve vatandaşlık hukuku Almanya'da tartışmaya açılmış ve bu konularda reform ihtiyacı duyulmuştur. Böylece göç gerçeği Alman devleti tarafından tanınmaya başlanmış ve bu yönde kısmen de olsa adım atmaya sevketmiştir. Kalifiye iş gücü ve "Green Card“ gibi düzenlemeleri içeren yasal değişiklikler yapılmıştır. Bunun yanı sıra 2007 yılında göç yasasında yapılan yeni düzenlemeler, bazı alanlarda göçmenlerin hayatını kolaylaştırmıştır. Ayrıca 2012 Nisan ayında hükümet yabancı ülkelerden alınan diplomaların tanınması yönünde mevzuat değişiklikleri yaparak bir nebze rahatlama sağlamıştır (Loeffelholz, 2013, s.101). Almanya Başbakanı Merkel ise bir konuşmasında "Geçen yıl Almanya' ya yüksek oranda göçmen geldi ve çoğu iyi ĕgitimliydi. OECD raporları da Almanya'nın göç için iyi şartlarda olduğunu ortaya koyuyor. Ancak Almanya hâlâ kapalı ve zor bir ülke olarak algılanıyor" diyerek göç politikalarından bahsederken Almanya'nın yurtdışındaki olumsuz imajına ilişkin bir de özeleştiri yapmıştır. Merkel “ABD'yi örnek göstererek hem iç pazarda hem de Avrupa genelinde istihdam açısından daha fazla devrime ihtiyaç duyulduğunu ve böylesi bir devrim için Avrupa'da çok dilliliği ve çokkültürlü toplumu kabul etmenin şart olduğunu“(Rede von Bundeskanzlerin Merkel beim zweiten Demografiegipfel, 2018) vurgulamıştır.

Homojen etnik yapıyı koruma refleksi ve çokkültürlülüğü red anlayışı genel kabul görmektedir. Her ne kadar Almanya'ya göçmen alımının ardından uzun süre geçmiş ve iki üç nesil göçmen bu ülkede doğup büyümüş olsa da Alman halkının bu süreçte bir göç ülkesi olduğunu kabul etmesi zaman almıştır. Almanya'nın bir göç ülkesi olduğunu de facto tanıması 90’lı yıllarda, yasal değişiklikler ise 2000 yılında yapılan "Vatandaşlık Yasası Reformu" ile başlamıştır.

Almanya eski içişleri bakanı Hans-Peter Friedrich, bakanlık tarafından organize edilen toplantıda ' 'Ihracat devi Almanya'nın ekonomik liderliğinin yanı sıra dünyaya açık tutumuyla tercih edilen bir göç ülkesi olabileceğini kaydetti. Friedrich bunun için başta ABD olmak üzere klasik göç ülkelerinin mercek altına alındığını" ifade etmiştir (Almanya demografik dönüşümle dünyaya açllıyor, 2017).

Federal hükümet, göçmen sayısı ve doğum oranların artırılması halinde nüfusta denge sağlanabileceğini her platformda dile getirmektedir. Hatta 2013 y1lındaki 6. uyum zirvesine, Başbakan Merkel "Uyum ülkesi olmak istiyoruz 
"sözüyle başlamış, göçmenlerin uyumunun önemine işaret etmiş ve geçen yıllarda bu düşünceyi ajandaya aldıklarını belirtmiştir. Federal hükümet, 2013 ve 2017 yılında olmak üzere iki demografik zirve gerçekleştirmiştir. Düzenlenen sayısız çalıştay, seminer ve konferansların yanında başbakanın, bakanların, sendikaların da programda yer alması Almanya'nın geleceği açısından ne kadar önemli olduğunu göstermektedir. Son olarak 2017'de tertiplenen Demografi Zirvesinde konuşan Angela Merkel 2025 y1lına kadar ülkede 6 milyon kişinin iş piyasası dışında kalacağına dikkat çekerek Almanya’nın hoşgörü ve hüsnü kabul kültürüyle dünyaya açılması gerektiğine işaret edip Avrupa' daki işsiz ve kalifiye gençlerin Almanya tarafından değerlendirimesi gerektiğini ifade etmiştir. (Almanya demografik dönüşümle dünyaya açılıyor,2017).

Özetle genel olarak göç süreci incelendiğinde, geçtiğimiz 50 yılda her yıl ortalama 150 bin yabancı Almanya'ya göç ederken, Almanya'nın tekrar birleşmesiyle göçmen sayısı her y1l 190 bine çıkmıştır. Ancak 2004 ve 2014 tarihleri arasında 203 bin ortalamasını yakalamıştır. 2015 yılında ise istisnai olarak 1,1 milyon mültecinin Almanya'ya iltica etmesiyle göçmen sayısı rekor düzeyde artış göstermiştir (Fuchs, Kubis, Lutz 2017, s.83).

Alman toplumunun göçmenleri kabulu uyumu kolaylaştıracak ve yeteneklerini ülkenin kalkınması için kullanmalarına vesile olabilecektir. Ülke ikinci dünya savaşından sonra sayısız göç akınından etkilenmiş ve gelenlerin sayısal açıdan katlanmasıyla birlikte artık göç ülkesi olduğunu kabullenmek durumundadır.

\section{Irkçılık, Yabancı Düşmanlığı ve Ayrımcılık}

\section{Göçmenlerin Çalışma ve Sosyal Hayata Uyumu}

81 milyonlu Alman nüfusunun 42 milyonu aktif iş piyasasındadır. Çalışan nüfus içerisinde 8 milyonu göçmen kökenli Alman vatandaşı, 4 milyonu yabancı ülke vatandaşı olmak üzere toplam 12 milyon çalışan göçmen kökenli bireylerden oluşmaktadır. 2015 yılındaki işsizlik oranları incelendiğinde toplam nüfusun \% 5'i oranında işsizlik kayıtlara geçmiştir. Bu işsizlik oranları içerisinde Alman nüfusunun 1,3 milyonu yani sadece \% 3.8`i işsizdir. Göçmen kökenli bireylerde bu oran \% 7.7 çıkmaktadır. Yabancı ülke vatandaşlarında işsizlik \%9.1 çıkarken Türk vatandaşlarında ise bu oran \% 20,9'a tekabül etmektedir (Arbeitsmarkt, 2017). 
Tablo 1

Almanya'da işsizlik oranları (Göçmen ve Alman vatandaşları arasında işsizlik oranların kıyaslanması)

\begin{tabular}{lllc}
\hline Almanya geneli aktif çalışan & 42 milyon & Almanya geneli işsizlik oranı & $\% 5$ \\
Göçmen Kökenli Alman vatandaşı & 8 milyon & Alman vatandaşları arasında & $\% 3,8$ \\
Yabancı ülke vatandaşları & 4 milyon & Göçmen Kökenli bireylerde & $\% 7,7$ \\
Toplam (göçmen ve başka ülke vatandaşı) & 12 milyon & Başka ülke vatandaşı & $\% 9,1$ \\
& & Türk vatandaşlarında & $\% 20,9$ \\
\hline
\end{tabular}

Tabloda görüldüğü gibi özellikle işsizlik rakamları incelendiğinde göçmenlerin işsizlik oranı Almanlara göre iki kat fazla iken Türk vatandaşlarında ise bu oranın üç kat fazla olduğu gözlemlenmektedir. Mültecilerin yarısının hali hazırda işsiz olduğu görülmektedir. Aynı zamanda çalışma ajansı verilerinde 2015 yılı içerisinde meslek eğitimini tamamlayan 13 bin kişinin meslek yeri bulma noktasında etnik yapısına göre farklı şekilde neticelendiği görülmüştür. 2015 yılı başında Alman vatandaşlarının \%44'ü meslek eğitimi için firmalarda yer bulurken bu oran göçmenlerde \%29 olmuştur. 2015 Federal Mesleki Eğitim Enstitü raporuna göre bilhassa 20-34 yaş aralığındaki genç göçmenlerin ortalama \%32 meslek sahibi değildir. Alman vatandaşlarında ise bu oran sadece $\% 11$ 'e denk gelmektedir. Alman vatandaşı gençlerden 1,3 milyon kişi meslek eğitimi alırken yabancı kökenli vatandaşlarda bu sayı 80.000'dir. Bu da tüm eğitim alanlar arasında \%8'e denk gelmektedir (Fluchtmigration,2017).

$\mathrm{Bu}$ veriler 1şığında bahsi geçen konu, göçmenlerin ve mültecilerin çıraklık eğitiminde karşı karşıya kaldıkları sorunları da ortaya çıkarmaktadır. Bu sorunların başında; yeterli sayıda çıraklık eğitimi yeri bulunamaması, gençlerin genel eğitimdeki başarı oranlarının Alman gençlerine kıyasla düşük olması, okullardan meslek eğitimine geçiş sürecinde bilgi ve motivasyon eksikliği, yanlış meslek seçimi, Alman işverenlerin çıraklık eğitim yerleri için eğitim durumları daha iyi olan Alman gençlerini seçmeleri ve bazı işverenlerin çırak seçiminde yabancılar aleyhine ayrımcı davranmaları gelmektedir. Bu nedenle eğitim sorunu göçün başlangıcından beri güncelliğini hiçbir zaman kaybetmemiştir.

Tabi bunun yanında göç serüveni ve süreçleri de değişmeye başlamıştır. Almanya'ya gelen ilk kuşak kesimden genel olarak işgücü göçünün başladığ 1 60’lı yılların başlarına kıyasla beklenti büyük oranda değişmiştir. O dönemler göçmenlerde aranan asıl nitelik çalışma becerisi iken zamanla teknolojinin hızla artmasıyla kalifiye veya meslek eğitimine sahip insanlara ihtiyaç artmıştır. Göçün ilk yıllarında vasıfsız işgücü ihtiyacının fazla olması gibi nedenlerle göçmenlerin 
büyük kısmı istihdam edilmiştir. Ancak 80‘li yıllardan sonra vasıfsız işçi ihtiyacının azalması ve kalifiye işgücü ihtiyacının artması bilhassa göçmenleri olumsuz etkilemiştir. Aynı zamanda iş piyasasında, iş verenler sadece mesleki niteliği olan işgücüne iş vermektedirler. Mesleki eğitim yeri bulamadığı için eğitim alamayan, diğer taraftan çalışacak işyeri bulmada sıkıntı çeken gençler vasıfsız işçi olarak iş piyasasında devam etmektedirler. Bilhassa Türk ve Arap kökenli bireylerde işsizlik oranlarının yüksek olması ve mesleki eğitim eksikliği gibi nedenlerden dolayı topluma uyum sağlamaları güçleşmekte ve sağlıklı bir sosyal yapıya sahip olarak hayatlarına devam etmeleri zorlaşmaktadır. Yabancıların büyük bir bölümü, istihdam piyasasının özellikle yüksek teknolojinin giderek daha fazla kullanıldığ 1 ve mavi yakalılara olan ihtiyacın azaldığı sektörlerde iş bulmakta zorlanmaktadır. Tabiatıyla bu durumun tek sebebi mesleki nitelik düzeyinin düşük olması değil aynı zamanda Alman işverenin öncelikli tercihini yaparken işgücü göçünün üzerinden uzun süre geçmesine ragmen yabancı kavramıyla bu denli saplantılı olmasıdır.

Almanya Avrupa genelindeki mülteci artışından en fazla etkilenen ülke olarak dikkat çekmektedir. Federal göç ve mülteci kurumu verilerine göre 2015 yılında Suriye krizine ve bölgesel nedenlere bağlı olarak rekor seviyede 1,09 milyon mülteci Alman makamlarına iltica başvurusu yapmıştır. 2016 yılında bu sayı düşerek 500 bine gerilemiştir. Bir kısmının ileri zamanda geri dönebileceği veya sınır dışı edilebileceği; ancak çoğunluğunun Almanya'da kalacağı ve iş piyasasında aktif olabilecek potansiyele sahip oldukları belirtilmektedir. Son verilere göre 2017`de 700 bin mülteci iş ararken tüm mülteciler arasında işsizlik oranları \%51,4 ile en yüksek oranı oluşturmaktadır (Fluchtmigration, 2017). İktidar partisi; aşırı sağdan gelen tepkiler üzerine iltica yasasını zorlaştırarak güvenli olmayan ülkelere sınırdışı sürecini hızlandırma kararı almıştır. Birçok insan hakları örgütünün tepki göstermesine rağmen düzenleme mecliste kabul edilmiştir. Eğitimleri devam eden, dil öğrenmiş, çalışan ve meslek sahibi olan bir çok mülteci, polis tarafından güç kullanılarak sınır dışı edilmiştir. Alman vatandaşlarının bu kararı protesto etmesine rağmen iktidar partileri aşırı sağın söylemlerine yenik düşmüştür.

Federal Göç ve Mülteci kurumunun göçmenlerin eğitimi ile ilgili yayınlamış olduğu raporda, göçmenlerin ve mültecilerin, Alman nüfusuna göre eğitim seviyesinin bariz şekilde farklı olduğu ve buna bağlı olarak iş piyasasına ve sosyal hayata katılımın zorlaştığı ve bunun da uyumu geciktirdiği belirtilmektedir (Migration, Integration, Asyl, 2018, s.23). Ancak 2000 ile 2015 y1lları kiyas- 
landığında "Der Sachverständigenrat deutscher Stiftungen für Integration und Migration"göre; bu yıllar arasında gelen göçmenlerin yüksek okul mezuniyet oranı iki kat artarak \%44‘ü bulduğu görülmektedir. Buna karşın kalifiye genç göçmenlerin başka ülkelere göç edişinde artış olduğu gözlemlenmektedir. Her yıl ortalama 700 bin göçmen Almanya dışında yaşamayı tercih etmektedir. $\mathrm{Bu}$ sonuç bir çok faktöre bağl1 olduğu gibi son senelerde artan İslamfobia ve yabancı düşmanlığı da önemli sebepler arasındadır (Viele Götter, ein Staat: Religiöse Vielfalt und Teilhabe im Einwanderungsland, 2018, s.31).

\section{Artan Irkçılık ve Sosyal Dışlanma}

Çoğu göçmen sosyal hayatın değişik mecralarında ayrımcılığa maruz kalmaktadır. Bilhassa iş hayatına girişte ayrımcılık sıkça yaşanmaktadır. Irkçı1ığın günlük yaşama yansımasından doğan sosyo-kültürel ve psikolojik sorunların yanı sıra yabancı düşmanlığı ve ırkçılık, ayırımcı işlemler, fırsat eşitliğine aykırı uygulamalar göçmenlerin yaşadığı sorunların başında gelmektedir.

Özellikle iş başvurularında etnik kökeninden dolayı başvurusu reddedilenler sayısı endişe vericidir. Bazı iş başvurularında gereğinden yüksek kalifiye eleman talep edilmesi sıkça yaşanan vakalardandır. Aynı şekilde birçok göçmene iş yerinde amiri ve iş arkadaşları tarafından etnik kökeninden dolayı mobing uygulanmakta veya kariyer imkânları kısıtlanarak alt seviyede iş sunulmaktadır. Meslek eğitimi alan başörtülü göçmenlerin iş kabulünden sonra başörtüsünü çıkarması teklif edilerek baskı unsuru oluşturulmaktadır. Buna benzer vakalar gündelik hayatta sıkça karşılaşılan sorunlardan bazılarıdır.

1990`lı yılların başından itibaren göçmen sayısının giderek artmasıyla ve medyada oluşturulan olumsuz göçmen algısına bağlı olarak şiddet olaylarında büyük artış meydana gelmiştir. Yabancı düşmanlığı aktif ve pasif düşmanlığı olmak üzere iki kategoride değerlendirilmektedir. Bu türlerin tanımlarına baktı̆ı̆ızda aktif yabancı düşmanlığı, kundaklama gibi cana ve mala yönelik çeşitli saldırı türleri şeklinde yorumlanmaktadır. Pasif yabancı düşmanlığı ise; yabancıları işe almama, kiralık ev vermeme, onları aşağılama, dışlama ve buna benzer şekillerde görülen yabancı düşmanlığı türüdür (Die demografische Entwicklung in Deutschland,2017).

Yabancılar arasında artan yüksek işsizlik oranlarının gayri safi milli hasılaya yük getirdiği ve yabancıların sosyal yardımlardan geçinme yoluna gittiği iddia edil- 
mektedir. İç politikada tartışma konularından biri olan bu eğilim Alman toplumunda yabancılara karşı bir önyargı oluşturmaktadır. Bilhassa çoğu Alman medyasında göçmenlerin, devletten aldıkları sosyal yardımlarla geçindikleri ve devlete yük olduklara yönünde haberler yayınlanmaktadır. Ancak buna karşın Bertelsmann Vakfi'nın raporunda; göçmenlerin devlete yılda 22 milyar avro katkı sağladıkları; iş, eğitim ve kültür-sanat gibi hayatın her alanında yer aldıkları ve topluma fayda sağladıkları belirtilmektedir gözlerden kaçmaktadır (Der Beitrag von Ausländern und künftiger Zuwanderung zum deutschen Staatshaushalt,2018, s.7).

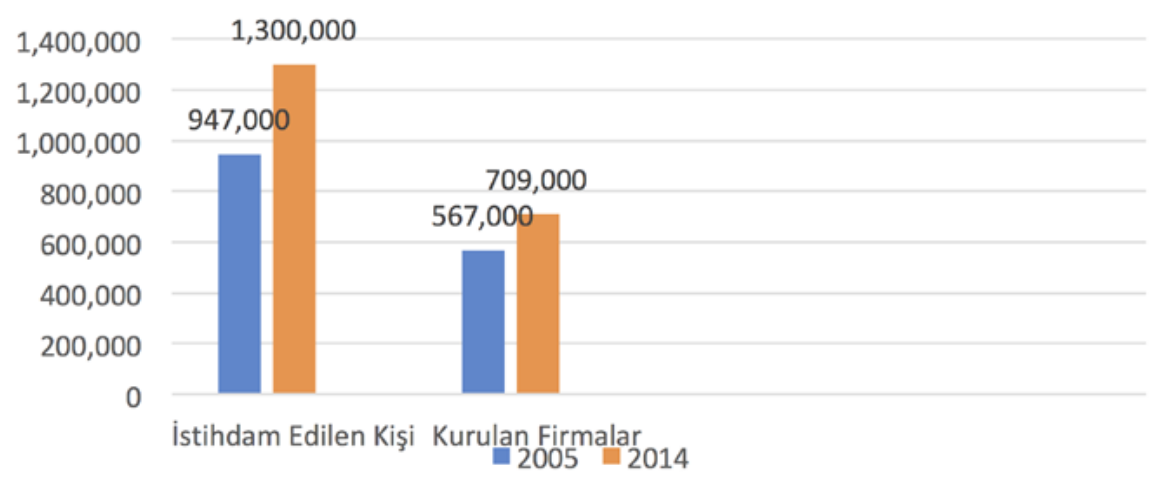

Grafik 2

Göçmenlerin kurdukları firmalar ve istihdam ettikleri kişi sayısı

2005 ve 2014 yılları arasında göçmenlerin istihdam ettikleri kişi sayısı 947 binden 1,3 milyona ulaşarak \% 36 artış göstermiştir. Aynı şekilde 2005 yılında 567 bin yabancı kökenli firma varken bu oran 2014 yılında 709 bine yükselerek \% 15 artmıştır. Dolayısıyla göçmenler sadece iş gücü olarak değil aynı zamanda kendi kurdukları firmalar ve oluşturdukları istihdamla da ülkenin gelişimine katkı sunmaktadır (Migrantenunternehmen sind Jobmotor für Deutschland, 2018).

$\mathrm{Bu}$ tartışma beraberinde Alman toplumunun işsiz kalma korkusunu ve göçmenleri rekabet aracı olarak görmelerini gündeme getirmektedir. Buna benzer tartışmalar, iç politikanın etkisiyle toplum içerisinde toleransın azalmasına sebep olmuş ve yabancılara karşı nefreti körüklemiştir. Federal Ayrımcılık Kurumu bir y1l boyunca kuruma gelen talepleri ve şikayetleri incelediği araştırmasında; daha çok çalışma koşulları, iş hayatı ve kariyerde yükselme ile ilgili taleplerin geldiğine işaret etmektedir. Çalışma hayatındaki dolaylı ve doğrudan ayrımcılıkla ilgili şikayet sayısı sürekli artmaktadır. Şikayetler incelendiğinde ise daha çok hakaret, tehdit ve mobing gibi konularda karşımıza çıkmaktadır. 
Başta çalışma hayatı olmak üzere, etnik köken, yaş, engellilik, yüz rengi ve cinsiyet gibi konular da şikayetler gelmektedir. Aynı zamanda etnik kökene dair ayrımcılıkla ilgili iş başvurularında ırkçılık yapılıp yapılmadığı araştırılmıştır. Ekonomi öğrencileri mesleki eğitim yeri bulabilmek için binin üzerinde başvuru yapmıştır. Araştırma sonucunda Türk ismiyle başvuranlar Alman ismiyle başvuranlardan \%14 daha az olumlu cevap almıştır. Hatta ufak işletmelerde ayrımcılık oranının \%24 ile daha yüksek oranda olduğu görülmektedir. Ayrıca Federal Ayrımc1lık Kurumu'nun 2017 raporuna göre 2013 ve 2016 yılları arasında ayrımcılıkla ilgili 9.099 şikayet ve danışma talebi gelmiştir. Bu talepler; çoğunlukla etnik köken olmak üzere engellilik ve cinsiyet odaklı şikayetleri içermiştir. Çalışma hayatında ayrımcılık \% 41 ile neredeyse gelen şikayetlerin yarısını oluşturmaktadır (Diskriminierung in Deutschland, 2017).

Ayrıca göçmenlerin istihdama girişlerinde eksikliği çekilen mesleki eğitim, deneyim ve beceri ile ilgili yaş gruplarına göre etkin teşvik tedbirlerinin alınması bu köklü sorunun orta ve uzun vadede çözümü için yararlı olacaktır. Almanya uyum bakanı Maria Böhmer göçmenlerin uyumu konusundan bahsederken "Özellikle göçmen kökenli gençlere en kisa yoldan para kazanmak yerine să̆lam bir meslek ĕgitimi almalarını ve bu ülkenin olanaklarından yararlanmalarını öneririm. Ayrıca işverenlere de gençlere daha fazla meslek eğitimi vermeleri konusunda çağrıda bulunuyorum. Zira onlar Almanya'nın potansiyeli ve geleceği" (Almanya demografik dönüşümle dünyaya açıllyor,2017) demiştir. Son dönemde göçmenlerin ve mültecilerin Alman toplumuna uyum sağlamadığ1 yönünde açık bir alg1 oluşturulmaya çalışılmaktadır. Kültürel farklılıklar sebebiyle Türk ve Arap vatandaşlarının Alman toplumuna uyumlarının mümkün olmadığı yönündeki tartışmalar devam etmektedir. Bilhassa töre cinayeti gibi olaylar üzerinden İslamiyet' in AB kültürüne uyum sağlayamadığı ve Türklerin dini inançları nedeniyle entegre olmayı reddettikleri şeklindeki görüşler ortaya çıkmıştır. Bunların yanında son yıllarda artmış olan mülteci sorunu tartışmaları, İslam karşıtı PEGIDA 'nın düzenlemiş olduğu gösteriler ve göçmenlere güvenlik güçleri tarafından sadece dış görünüşlerinden ötürü sık sık kötü muamele yapıldığına dair şikayetler gündemdedir. Göçmenlerle ilgili haberler ve olumsuz önyargılar yoğun olarak gündeme gelmektedir. Federal Kriminal Dairesi 2016 verilerine göre; mülteci kamplarına 996 saldırıdan 169‘u şiddet içermektedir. Bu saldırılardan 120`si mülteci kamplarının ateşe verilmesi şeklinde gerçekleşmiştir (Bericht zur polizeilic- 
hen Kriminalstatistik, 2017). Aynı şekilde Alman Federal Emniyet Teşkilatı Almanya' da 8 bin 991 mülteci çocuğun kaybolduğu ve bu çocukların hala da bulunamadığını bildirmektedir (BKA: 8 bin çoçuk sığınmacı kayıp, 2018).

11 Eylül saldırısının ardından Batı'da islamofobinin ve yabancı düşmanlığının giderek artmasıyla yabancılar ve özellikle de Müslüman azınlık, iş piyasasından direk etkilenmektedir. Süreç içerisinde kamuoyundaki olumsuz Müslüman ve göçmen algısı her yıl katlanarak artmıştır. Bugünkü süreçte de aşırı sağın güçlenmesiyle devam etmektedir. Hatta ülkedeki seçim propagandalarında göçmenler ve Müslümanlar, özelde Almanya' daki Türkiye kökenli bireyler tartışmalarda birincil gündem maddesi olmaya başlamıştır. Bu algıya mukabil 2001 ve 2011 yılları arasında her yıl camilere ortalama 22 saldırı olurken 2015 yılında 55; 2016 yılında ise 71 saldırı gerçekleşmiştir. Bu durum, Alman makamlarının yeterince önlem alıp almadığ 1 ve faillerin bulunması için yeterince çaba gösterip göstermediği endişelerini akla getirmektedir (Diskriminierung,2018).

Öte taraftan 2011 yılında tesadüfen ortaya çıkan NSU terör örgütünün 10 göçmen kökenli bireyi öldürmesi, geçen bu süre zarfında örgütün son üyesi Beate Zchaepe'nin yargılanmasına devam edilmesi, şahitlerin esrarengiz bir şekilde ölü bulunması ve devletin bu süreçte uzun bir süre yer altında kalan örgütü tespit edememesi kamuoyu tarafindan sorgulanmaktadır. Bu konuda Alman hükümeti ombudsman olarak görevlendirdiği Barbara John durumu "yaşananlar henüz daha kapanmış değil. Birçok şey hala aydınlanmadı ", diye ifade ederken Almanya'nın çeşitli eyalet meclislerinde toplamda 14 araştırma komisyonunun çalışma yürütmesine rağmen hiçbir ilerleme kaydedilememesini eleştirmektedir (NSU davası ombudsmanı John: Cinayetlere ilişkin birçok şey hala aydınlatılmadı ,2017).

Her ne kadar ayrımcılığın önlenmesi için farklı projeler uygulansa da dolaylı ayrımcılığın yapıldı̆̆ı ve bunun tespitinin zor olduğu anlaşılmaktadır. Yaşlı nüfusun arttığı düşünülürse gelecekte kalifiye eleman bulma sıkıntısının daha çok artacağı aşıkardır. Almanya'da doğup büyüyen göçmen kökenli insanların potansiyelinden faydalanarak muhtemel eleman ihtiyacının giderileceği beklenmektedir. Ancak kalifiye göçmen kökenli gençlerin meslek eğitimi ve iş kabulünde yaşadıkları sıkıntılar ümitlerini kırmaktadır. 


\section{Demografik Dönüşüm ve Göç}

\section{Nüfusun Yaşlanması}

Demografik dönüşüm; nüfus yapısı, istatistik, sosyal güvenlik ve sürdürülebilir ekonomi gibi bir çok parametrenin ele alınması ile planlanmaktadır. Ortalama ömür süresinin değişimi ile birlikte gelecek yıllarda ülkelerin ve eyaletlerin nüfus yapısı farklılık gösterecektir (Schimany, 2003, s.29). Bebek ölüm oranlarının azalması ve gelişen tıp teknolojisiyle birlikte ortalama ömür süresinin artması gibi nedenler demografik dönüşümü hızlandıran faktörler arasındadır.

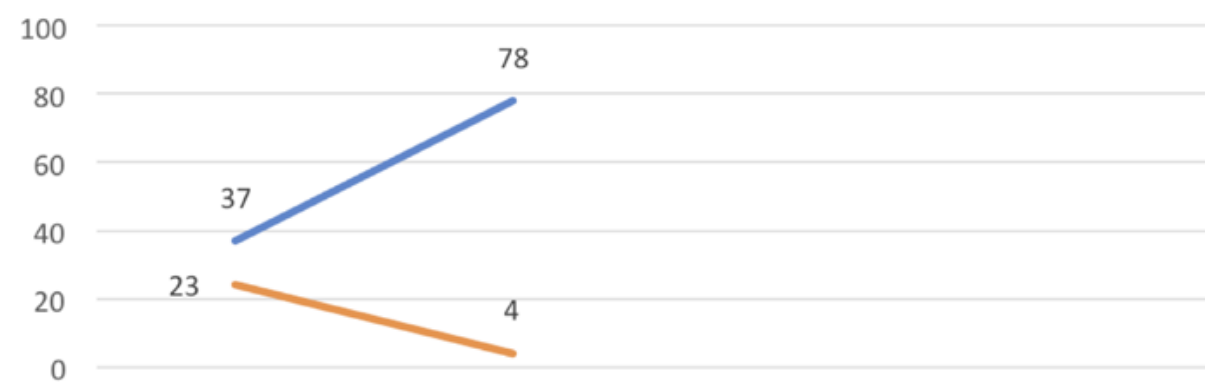

\section{-1750-2000 Bebek Ölümleri}

Grafik 1

Ortalama ömür süresinin değişimi ve Bebek ölüm oranları

Almanya' da 1750 ile 2000 yılları arasında insanların ortalama ömür süresi iki kat artarak ortalama 37 yaşından 78 yaşına çıkmıştır. Aynı zamanda bebek

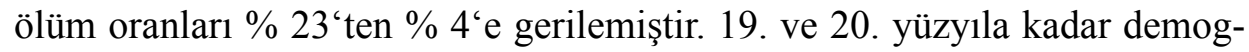
rafik dönüşüm genel olarak düşük bir seyir izlemiş; ancak son iki yüzyılda düşük ölüm oranı ve azalan doğum oranı gibi nedenlerle gelişmiş ülkelerde bu trend giderek artmıştır. Buna bağlı nedenlerle 60 yaş üzeri birey sayısı çoğalmıştır (Ehmer, 2008, s.162).

Almanya' da 1970 yılı başlarında ikinci demografik dönüşüm süreci başlamıştır. Doğum oranı giderek azalma eğilimi göstererek kadın başına doğum \% $1,4^{'}$ e gerilemiştir. Bu süreçten sonra nüfus sayısı sürekli düşmeye başlamıştır. Ancak nüfusun artması göçmenlerin gelmesine bağlı olarak çoğalmıştır. 1900 yılında Almanya'da nüfusun \%45'i 20 yaşın altındayken \%5‘i 65 yaş üzerindeydi. Güncel verilere göre 2060 yılına kadar 20 yaşın altında olanlar 1/3 oranında azalırken, 65 yaş üzeri olanların sayısı çoğalacaktır. Sadece 2015 
y1lında doğum açığ $1 \% 2,3$ 'tü ve 1000 kişilik nüfusa bağlı olarak 190 bin açık nüfus olmuştur. Ayrıca her 4 göçmenden 3'ü Almanya'da sürekli kalmaktadır. Bu artış devam ettiği takdirde 2050 yılına kadar göç nüfusunun tüm nüfusun \% 27,9'una ulaşacağ tahmin edilmektedir. (Kaufmann, 2018, s.1-3)

Eski Almanya Başbakan Yardımcısı Franz Müntefering Akdeniz Üniversitesi'ndeki 'Dünya'da Demografik Dönüşüm ve Değişim: Almanya' da yaşlı sorunları ve çözümleri‘ başlıklı seminerdeki konuşmasında: „, Şu anda 65 yaş ve üstü insanlar toplumun yüzde 20 'sini oluşturmaktadır. 2040 yılında ise bu oran yüzde 30 'a çıkacak. Almanya, daha uzun süre insanlara emeklilik maaşı ödeyecek. Bu durum uzun süre devam edecek gibi görünüyor. Tabi ki sosyal emeklilik sisteminin finanse edilmesi önümüzdeki yıllarda gitgide zorlaşacak. Emeklilik paraları da çalışanların kesintilerinden karşılanacak. Eskiden Almanya 'da 6 kişi çalışır ve bir emeklinin parasını öderdi ama bugün 3 kişi çalışıp, bir emeklinin maaşını ödeyebiliyor. 2030 yılında ise 2 kişi çalışıp 1 kişinin emeklilik parasını ödeyecek (İşte 2050〉de Almanya`yı bekleyen büyük tehlike, 2018)“diyerek tehlikenin boyutlarını açıklamıştır.

Siyasi aktörler dönem dönem bu sorunu gözler önüne çıkaran konuşmalar yaparak meseleyi gündeme taşımaktadır. Federal Aile, Kadın ve Gençlik Bakanlığı demografik dönüşüm konusunda halkın düşüncesini ve bilgisini incelemek üzere Allensbach Enstitüsü'ne kamuoyu araştırması yaptırmıştır. Birçok gence, demografik dönüşümden korkup korkmadığı ve konu hakkında bilgileri sorulmuştur; 20-32 yaş aralığındaki 1097 kişinin hemen hemen hepsi konuyu bildiklerini söylemiştir. Gençlerin 2/3'si demografik dönüşümün gelecekte ciddi bir sorun olacağı hususundaki endişelerini paylaşmıştır. Buna karşın gençlerin sadece \%23 'ü demografik dönüşümün iş piyasasında daha çok firsat getireceğini düşünmektedir (Brauchen wir wirklich mehr Kinder?, 2017).

21. yüzyılda Almanya'da nüfus sayısı giderek azalma eğilimine devam etmekte ve nüfus oranında yaşı ıireylerin sayısı hızla artmaktadır. Bu dönüşümde göç yoluyla denge sağlanmadığı takdirde gelecek yıllarda yaşı nüfusun çoğunlukta olacağı ve sosyal güvenlik sisteminin işleyişinin istenilen düzeyde devam edemeyeceği aşikardır. Bu süreç zamanla ekonominin büyümesine, eğitim sistemine ve teknoloji alanında da gelişmeye mani olacak ve iş üretim hacminin düşmesiyle ülkenin kalkınmasını etkileyeceği düşünülmektedir. 


\section{Demografik Dönüşümün Etkileri ve Göç İhtiyacı}

Alman nüfusunun yaş ortalması 2030-2040 yılına kadar her y1l 2.2 oranında artacaktır. Bütün modeller gelecek nüfus gelişimini bu şekilde göstermektedir. $\mathrm{Bu}$ nedenle demografik dönüşüm, göç ve iktisat konusu birbirine sıkı sıkıya bağlı konulardır. Hatta gelecekteki iktisadi kalkınma da demografik dönüşümle bağlantılı olacaktır (Kistler ve Hilpert, 2018, s.2). Alman Ticaret ve Sanayi Odası bu konuda yayınladığı raporda şöyle demiştir: "İş piyasasında çalışacak kişilerin sayısı demografik dönüşümden etkilenmektedir. Potansiyel iş gücü saylsl giderek azalırken buna paralel yaşlı nüfus da artmaktadır. İs gücü eksikliğ $i$ bugünden görünür olmaya başlamıştır. Özellikle kalifiye iş gücü ihtiyacı giderek daha çok artmaktadır." Öte taraftan Alman istatistik kurumu; Her y1l ülkeye en az 500 bin göçmen gelmesi gerekirken, 2004-2010 yılları arasında gelen göçmen sayısında azalma olduğunu, buna karşılık 2008-2012 yılları arasında gelen daha fazla göçmenin Almanya'yı terk ettiğini bildirmektedir. Dolayısıyla gelen göçmen ile giden göçmen arasındaki fark yılda 280 bine ulaşmıştır (Statistisches Jahrbuch Deutschland und Internationales 2015, 2018).

Kalifiye eleman ihtiyacı çok farklı noktalardan siyasetin gündeminde yer almaktadır. Kalifiye eleman sağlama potansiyelinin federal düzeyde ortaya çıkması bir çok eyaletin öncelikleri arasındadır. Kalifiye eleman ihtiyacı sektörel ve bölgesel olarak farklılık göstermektedir. Özellikle tıp, bakım hizmetleri ve teknik alanlar gibi küçük ve orta ölçekli şirketlerde bile sıkça açık ilanlarla karşılaşılmaktadır. Dönemin çalışma Bakanı Ursula von der Leyen (CDU- Hristiyon Demokrat Partisi) "2025 y1lına kadar potansiyel iş göçünün 6 milyon azalacağını bildirip buna karşın genç insanların meslek sahibi olmamasının işsizliği tetikleyeceğini belirtmiştir. Ayrıca çocuk yetiştiren kadinların tekrar kariyere dönme potansiyeline sahip olduğunu "bildirmektedir (Wer alt wird, muss flexibel sein, 2018). Gelecek 15 y1lın ziyan olacağını gerekli önlemler alınmazsa bu dönemin karanlık bir dönem olacağını vurgulamaktadır. Benzer ifadeler Alman Ticaret ve Endüstri Odası başkanı Hans Heinrich Driftmann tarafından da kullanılmıştır. "Yurtdışından kalifiye eleman istihdamı için Almanya'nın daha çok tanıtımının yapılmasını ve göçmenlere yönelik olumsuz algının düzeltilerek ülkelerine gelinmesinin sağlanmasının önemini “vurgulamıştır (Deutschland schrumpft, Merkel mahnt,2018).

Öte taraftan 1990 y1lından itibaren göçmen kökenli şirketlerin her y1l iki kat artarak katlandığını araştırmalar ortaya çıkarmaktadır. Her 6 şirketten 
biri göçmen kökenli kişiler tarafından kurulmuştur. $\mathrm{Bu}$ denli sayının fazla olması Almanya için önemli imkânlar oluştururken aynı zamanda göçmenlerin bu girişimcilikten faydalanması gerektiği ortaya çıkmaktadır. Mannheim Üniversitesi’nin araştırmasına göre Almanya'da 2,2 milyon göçmen kökenli kişi şirketlerde çalışmaktadır. Bu şirketlerin çoğu Türkiye kökenli bireylerden teşekkül eden şirketlerden oluşmaktadır.

Göçün ilk yıllarında göçmenler tarafından kurulan işletmeler orta ölçekliyken, günümüzde yerinİ büyük işletmelerin almaya başlaması önemli gelişmelerdendir. Araştırma aynı zamanda göçmen kökenli şirketlerin daha çok metropollerde yoğunlaştığını göstermektedir. Değişen süreçte göçmenler, iş piyasasında yeni alanlar ve imkânlar oluşturmaktadır. Artık birçok meslekte, çok dillilik ve kültürlülük etnik nüfusun çeşitlenmesi ile önem kazanmıştır. Dolayısıyla göç ekonomisi, bilimde ve toplumda güçlü bir şekilde hissedilmeye başlanmıştır. Bu yönüyle göçmen girişimciler de önemli potansiyel barındırmakta ve ülkenin kalkınmasına önemli imkânlar sunmaktadır (Schröder, Jain ve Lücker,2017).

Almanya düzenlediği ilk demografik dönüşüm zirvesi ile federal düzeyde demografik dönüşümün önemini gözler önüne sermiştir. Merkel zirve sonrası ,die Zeit` gazetesine verdiği röportajda Yaşlanan nüfus söyleminin abartıldığı yönündeki soruya karşılık genç nüfusun artan yaşlı nüfusu finanse etmek zorunda olduğunu aksi takdirde sosyal güvenlik sisteminin işlemesinde sıkıntılar çıkabileceğini belirtmiştir. Yaşlanan nüfusla birlikte azalan nüfusun devletin farklı alanlarına da etkisi olacağını dile getirip sadece devlet bütçesi değil aynı anda farklı sosyal sistemlerin idaresini de güçleştireceğini vurgulamıştır. Aynı zamanda en büyük riskin sadece emeklilik ya da bakım sigortası olmadığını sağlık sisteminin tamamının da direk olarak etkileneceğini söylemiştir (Besser Leben im Alter, 2017). Diğer bir söyleyişle 2013 yılında Merkel konunun önemine binaen demografik dönüşümün mega trend olduğunu söylemektedir. Hatta demografik dönüşüm bakanlığ1 kurulması yönündeki taleplerin gelmeye başlamasını Almanya’nın geleceği için önemli bir tema olduğuna işaret ederek: ' 'Toplumumuzda derin bir dönüşüm yaşanırken demografik dönüşüm hayatın her alanında yaşanmaktadır. Gerekli önlemler alınmazsa şehirlerde ve ülkede bu etkiler uzun süreli devam edecektir. Federal hükümet bu yüzden kapsaml demografik strateji geliştirmekte ve toplumun bütün grupların harekete geçirmeye çalışmaktadır" (Zusammenhalt im demografischen Wandel, 2018) ifadesiyle gelecekle ilgili endişelerini paylaşmaktadır. 
Demografi dönüşüm tarihi ile ilgili çalışmalar yürüten Tarihçi Thomas Byrant Batı Avrupa ülkelerinde sürekli olarak yaşlanan nüfus ve göç ilişkisi rasyonel bir şekilde ele alınmadığı hususunda eleştirilerini dile getirmektedir. Almanya'da tartışma olağan dışında dramatize edilerek gündeme getirilmektedir. Tartışma daha çok çöküş korkularının gölgesinde kalmaktadır. Bir çok bilim adamı, siyasetçi ve diğer kamusal şahsiyetler azalan doğum oranını ulusal trajedi olarak görmelerinden dolayı eleştirmektedir (Brauchen wir wirklich mehr kinder ?,2018).

Genç nüfus oranı ağırlıklı olarak göçmen nüfustan oluşmaktadır. Özellikle 25 ve 45 yaş aralığındaki çalışanlar daha çok göçmenlerden oluşmaktadır. Sosyal Araştırmalar Merkezinde göç üzerine çalışmalar yürüten Dr. Andreas Sieger "Göç olmadan içme suyu ve altyapı giderlerinin dramatik bir şekilde artacağını, okulların kapatılacağını ve zamanla STK'ların cazibelerini yitirerek kültürel kuruluşların da kapanmak zorunda olacağını" belirterek sürecin ilerleyen zamanlardaki muhtemel risklerinin altını çizmektedir (Migranten am Arbeitsmarkt in Deutschland,2017). En son 2017 yılında yapılan II. Demografi Dönüşüm Zirvesinde konuşan Merkel; bu dönüşümde "toplumsal bağl1lıktan" bahsetmiş ve gençlerin toplumun geleceğinde aktif olmasının ve aile kurmasının önemine değinmiştir. Demografik dönüşümle neden bu kadar ilgili olduklarını açıklayan başbakan, 'gelecek yüzyllda toplumun istikrarla kalkinmasını arzuluyarsak artan yaşlı nüfusa karşı genç nüfusu da aynı oranda karşılamalıyı"” (Merkel: Sozialen Zusammenhalt starken, 2018) " diyerek konu hakkında yorum yapmıştır.

Göçün gerekliliği hususunda uzmanlar da siyasetçilerle aynı fikirleri paylaşmaktadır. Akademisyen Hans Werner Sinn demografik dönüşümden bahsederken "Almanya dinamik bir halka ve dünya sahnesinde güçlü bir ekonomiye sahip olmaya devam etmek istiyorsa muhakkak göçe ihtiyacı olduğuna önemle değinmektedir. Yaşlanan Almanya'nın hali hazırdaki refahını ciddi şekilde tehdit edeceğini gözler önüne sermektedir (Sinn, 2013, s.3-23). Hatta Almanya' da Eylül 2017 genel seçimleri yaklaşırken CDU iktidar partisi; seçim kampanyasında dijitalleşmenin öneminin yanı sıra yaşlanan Alman toplumunun istikbalini garanti altına alabilme adına aile/ çocuk vurgusuna ve demografik dönüşüme bağlı göç politikalarına değinmiştir.

Göçmenlerin potansiyelinin ortaya çıkması için ticaret odaları, yüksek öğretim kurumları, bölgesel yönetimler göçmen organizasyonları ile sık sık iletişim kurarak Almanya'nın dünyaya açık olduğu imajı verilmelidir. Bilhassa 
Almanya' da doğup büyüyen göçmen kökenli bireylerin potansiyelinden faydalanarak muhtemel eleman ihtiyacının giderilmesi beklenmektedir. Ancak gündelik hayatta ve basında göçmen kökenli bireyler rencide edilerek bu bireylerin ümitleri kırılmaktadır. Her türlü çabaya rağmen nüfus artışı sağlayamayan Berlin hükümetinin ülke içerisinde bulunan göçmenleri rencide edici söylem ve politikalardan kaçınması elzem görülmektedir.

\section{Sonuç}

Demografik dönüşüm meselesi her ne kadar geçmişte gündeme gelmemiş olsa da gelecek yüzyılda bilhassa gelişmiş ve gelişmekte olan ülkelerde medya, politika ve gündelik hayatın bir parçası olacaktır. Bilhassa doğum ve ölüm oranındaki değişimler, dünya çapındaki nüfus ve yaş yapısını değiştirecektir. Ömür ortalamasının artması; iş piyasası, emeklilik sistemi ve kamu kurumlarında siyasi ve yapısal değişikliklere neden olacaktır.

Almanya örneğinde projeksiyonlara göre, gelecek 20 yılda dışardan göç almadan Alman nüfusunun artmayacağı net bir şekilde görülmektedir. Tekrar göç artışı olmaması halinde Alman nüfusu 2050‘de 80,9 milyondan 66 milyona düşecek; işgücü ise 16,2 milyon gerileyecektir. Diğer bir deyişle çalışan işgücü \%36 düşecektir. Bertelsmann Stiftung gibi araştırma merkezleri bu nedenle her sene yarım milyon göçmen gelmesi gerektiğini belirtmektedir. Bilhassa Almanya'nın göç nüfusunu artırmasıyla bu demografik dengeyi korumaya yönelik tedbirler alması yadsınamaz bir gerçek olmuştur. Buna karşın geçen 20 sene incelendiğinde Almanya' da eğitim alan yabancıların her sene en az 475 bininin ülkeyi terk ettiği görülmektedir.

Sonuç olarak kalifiye eleman ihtiyacını karşılama imkanı olmasına rağmen sistematik yabancı düşmanlığı, eğitimli insanların ülkeyi terk etmesine neden olmaktadır. Göçmenlerin meslek yeri bulamaması, iş aramada yaşadıkları sıkıntılar ve göçmenlerde yüksek işsizlik oranları; vasıflı ve vasıfsız bir çok yabancı ülke vatandaşlarını demoralize etmektedir. Ayrıca Almanya'da aşırı sağ partilerin yükselişe geçmesi ve seçim propagandalarını yabancı düşmanlı$\breve{g} 1$ üzerinden yapmaları toplumdaki kanaatleri olumsuz etkilemektedir. Zaman zaman aşırı să̆ hareketlerin artması ve ırkçı saldırıların sistematik olarak çogalması da buna eklenebilir. Bilhassa merkez partilerin de bu rüzgara kap1larak aşırı sağ hareketlerine karşı tedbir almaması, bilakis zaman zaman oy 
kaybı yaşama uğruna ırkçı söylemlere kapılabilmesi endişe vericidir.

Resmi makamların ve siyasi aktörlerin de hemfikir oldukları şey göçmenler olmadan ülkenin kalkınma hamlesinin devam edemeyeceği yönündedir. $\mathrm{Bu}$ gerçekle Almanya işgücü ve kalifiye eleman açığını öncelikle AB ülkeleri içerisinde telafi etmek istemişse de geçen bu süreçte beklenen verim alınamamıştır. $\mathrm{Bu}$ nedenle $\mathrm{AB}$ dışındaki ülkelerden gelebilecek kalifiye eleman talebini karşılamak için yeni teşvikler ve düzenlemeler yapılmasına rağmen göçmenlere yönelik olumsuz imaj ve politikalar, kalifiye elemanlarda tereddüt oluşturmakta ve onları başka ülkeleri tercih etme durumuna itmektedir. Gerek ülke içerisindeki göçmenlerin iş piyasasına uyumuna, gerekse ülke dışında kalifiye elemanların Almanya'yı tercih etmesinin ülkenin iktisadi büyümesi için vazgeçilmez olduğu gerçeğine karar vericiler sürekli değinmektedir.

Bu konuda Merkel katıldığı zirvelerde ve toplantılarda ,yetişmiş göçmenlere yönelik gözlerini kapatamayacaklarını bildirirken eski çalışma bakanı Ursula von der Leyen de göçmenlerin Alman iş piyasası için gerekli olduğunu sık sık vurgulamıştır.

Modernleşme ve merkez-çevre teorileri göçle ilgili ülkelerin ve toplumların iki farklı bakış açısını yansıtmaktadır. Modernleşme kuramı göçmenlerin ülkelere sunduğu ekonomik katkıdan, kültürel ve sosyal hayatın çeşitlenmesi gibi avantajlardan bahsetmektedir. Yaşlanan Alman nüfusuna alternatif farklı teşvikler denendiyse de göç almadan ülkenin nüfus dengesinin ayakta kalamıyacağı araştırma sonuçlarında görülmektedir. Tam bu nokta da modernleşme kuramı da göçmenlerin katkılarına odaklanılması gerektiğini savunmaktadır. Ancak toplum ve siyasiler içerisinde göç aleyhine düşünceleri olanlar da azımsanmayacak derecededir. Bu açıdan merkez-çevre teorisi yaşanan göçlerin olumsuz yönlerini ele almaktadır. Göçmenleri ülkelerin kalkınması açısından yetersiz bulmakta ve ülkenin ekonomisine yük olacağ d düşüncesindedir.

Demografik dönüşüm önce göçmenler, son dönemlerde ise mülteciler üzerinden tartışılmaya devam edecektir. Alman nüfusunun \%20'sini göçmen kökenlilerin oluşturduğu ve gelecekte sayıları artacak olan yabancılarla bu oranın daha da artacağı göz önüne alındığında bu ülkenin gelecekte daha fazla oranda çok dinli ve çokkültürlü toplumlarla aynı kaderi paylaşacağı dolayısıyla ayrımcılığa karşı gerekli önlemleri alması ve yetenekli göçmenleri ülkesinde tutmayı başarması gerektiği söylenebilir. 


\section{Kaynakça/References}

Annette T. I. (2003). Migration in modernen Gesellschaften. Weinheim/ München: Juventa Verlag

Bade, Klaus (Ed.): (1992). Deutsche im Ausland - Fremde in Deutschland.Gütersloh: Bertelsmann Verlag.

Şahin, C. (2001). Yurtdışı göçün bireyin psikolojik sağlığ üzerindeki etkisine ilişkin kuramsal bir inceleme. Gazi Ĕgitim Fakültesi Dergisi, 21(2), 57.

Fuchs, J., Kubis A., Lutz, S. (2017). Langfristiges Erwerbspersonenpotenzial und Zuwanderungspotenziale: Regionale Implikationen.Bonn: BBSR-Online-Publikation Nr. 04/2017

Loeffelholz, H. (2013). Arbeitsmarkt, Fachkräftemangel und Anerkennungsgesetz, in: K.-H. Meier- Braun, R. Weber (Ed.): Deutschland Einwanderungsland. Tübingen: Kohlhammer Verlag

Münz, R., Seifert, W., Ulrich, R. E. (1997). Zuwanderung nach Deutschland Strukturen, Wirkungen, Perspektiven. Frankfurt: Campus Verlag

Oswald, I. (2007). Migrationssoziologie. Basel: Utb Verlag

Martin, P. (1991). Bitmeyen öykü: Batı Avrupa'ya Türk işçi göcü, Uluslararası Çalışma Bürosu, Ankara, 51.

Peter, S. (2003). die Alterung der Gesellschaft, Ursachen und Folgen des demographischen Umbruchs. Frankfurt.New York: Campus Verlag.

Schubert, K., Klein, M. (2011). Das Politiklexikon, Begriffe, Fakten, Zusammenhange. Bonn: Bundeszentrale für politische Bildung

Sinn, Hans-Werner (2013). Das demographische Defizit - die Fakten, die Folgen, die Ursachen und die Politikimplikationen, ifo Schnelldienst 21/2013 - 66. Jahrgang - 5. November 2013.

S. N. Eisenstadt (1953). Analysis of patterns of immigration and absorption of immigrants, Population Studies, 7(2), 167-180.

Kistler, E., Hilpert M. (2002). Auswirkungen des demographischen Wandels auf Arbeit und Arbeitslosigkeit, Bundeszentrale für Politische Bildung, Aus politik und Zeitgeschichte, 2001

Almanya demografik dönüşümle dünyaya açılıyor, Erişim Tarihi:03.06.2017,

http://www.dw.com/tr/almanya-demografik-

$\mathrm{d} \% \mathrm{C} 3 \% \mathrm{~B} 6 \mathrm{n} \% \mathrm{C} 3 \% \mathrm{BC} \% \mathrm{C} 5 \% 9 \mathrm{~F} \% \mathrm{C} 3 \% \mathrm{BCmle}-\mathrm{d} \% \mathrm{C} 3 \%$ BCnyaya-a $\% \mathrm{C} 3 \% \mathrm{~A} 7 \% \mathrm{C} 4 \%$

B11\%C4\%B1yor/a-16812514

Diskriminierung, Erişim Tarihi: 02.03.2017, https://mediendienst-integration.de/desintegration/diskriminierung.html\#c59

Arbeitsmarkt, Erişim tarihi:05.03.2017

https://mediendienst-integration.de/integration/arbeitsmarkt.html 
Fluchtmigration, Erişim Tarihi: 11.11.2016, https://statistik.arbeitsagentur.de/Statischer-Content/Statistische-Analysen/Statistische Sonderberichte/Generische-Publikationen/Fluchtmigration.pdf\#page $=4$

Diskriminierung in Deutschland, Erişim Tarihi: 20.06.2017, http://www.antidiskriminierungsstelle.de/SharedDocs/Downloads/DE/publikationen/ BT_Bericht/Gemeinsamer_Bericht_dritter_2017.pdf?_blob=publicationFile \&v=10

Deutschland schrumpft, Merkel mahnt, Erişim Tarihi: 11.10.2017, http://www.spiegel.de/politik/deutschland/bundesregierung-fordert-dialog-ueber-dendemografischen-wandel-a-859561.html

Zusammenhalt im demografischen Wandel, Erişim Tarihi:07.06.2018, https://www.bundeskanzlerin.de/ContentArchiv/DE/Archiv17/Reden/2013/04/201304-25-merkel-ethikrat.html

Merkel: Sozialen Zusammenhalt stärken, Erişim Tarihi: 07.08.2018, https://www.bundesregierung.de/Content/DE/Artikel/2017/03/2017-03-16demografiegipfel.html

Bevölkerung mit Migrationshintergrund, Erişim Tarihi: 20.08.2017 https://www.destatis.de/DE/PresseService/Presse/Pressemitteilungen/2017/08/ PD17_261_12511.html

BKA: 8 bin çoçuk sığınmacı kayıp, erişim tarihi: 30.08.2018 https://www.dw.com/tr/bka-8-bin991\%C3\%A7ocuks\%C4\%B1\%C4\%9F\%C4\%B1n mac\%C4\%B1-kay\%C4\%B1p/a-19510145

Viele Götter, ein Staat: Religiöse Vielfalt und Teilhabe im Einwanderungsland, Jahresgutachten 2016 mit Integrationsbarometer, erişim tarihi 31.08.2018 https:/www.svr-migration.de/wp-content/uploads/2016/04/SVR_JG_2016-mitIntegrationsbarometer_WEB.pdf

Migration, Integration, Asyl (Politische Entwicklungen in Deutschland 2017), Erişim tarihi: 26.03 .2018

http://www.bamf.de/SharedDocs/Anlagen/DE/Publikationen/EMN/Politikberichte/ emn-politikbericht2016germany.pdf;jsessionid=4C0954B5B2ACF653D03874CE9F0 462B7.2_cid286?_blob=publicationFile

Statistisches Jahrbuch Deutscland und İnternationales 2015, Erişim tarihi: 23.04.2018 https://www.destatis.de/DE/Publikationen/StatistischesJahrbuch/StatistischesJahrbuch2015. pdf?_blob=publicationFile

Wer alt wird, muss flexibel sein , Erişim tarihi: 02.04.2018

https://www.sueddeutsche.de/politik/merkel-auf-berliner-demografiegipfel-wer-altwird-muss-flexibel-sein-1.1486994 
Wir riefen Arbeitskräfte und es kamen Menschen, Erişim tarihi: 05.09.2018 https://www.fazschule.net/project/die-welt-in-bewegung2011/897

Bevölkerungsrückgang als Problemgenerator für alternde Gesellschaften ( Franz-Xaver Kaufmann) erişim tarihi: 03.09.2018 https://www.boeckler.de/wsimit_2007_03_kaufmann.pdf

Von der „Gastarbeiter“-Anwerbung zum Zuwanderungsgesetz, Erişim Tarihi: 03.07.2018 http://www.bpb.de/gesellschaft/migration/dossier-migration-ALT/56377/ migrationspolitik-in-der-brd?p=al

Asylbewerber in BRD, Erişim tarihi:03.06.2018

https://www.berlin-institut.org/online handbuchdemografie/bevoelkerungspolitik/deutschland/asylbewerber-in-der-brd.html

Die deutsche “Green Card”, Erişim tarihi: 02.04.2018 http://focusmigration.hwwi.de/typo3_upload/groups/3/focus_Migration_Publikationen/Kurzdossiers/KD03_Green_Card.pdf

Rede von Bundeskanzlerin Merkel beim zweiten Demografiegipfel, Erişim tarihi: 07.05.2018 https://www.bundesregierung.de/ContentArchiv/DE/Archiv17/Reden/2013/05/201305-14-merkel-demografie.html

Die demografische Entwicklung in Deutschland, Erişim tarihi: 03.08.2017 http:/www.bpb.de/politik/innenpolitik/demografischer-wandel/196911/fertilitaetmortalitaet-migration

Der Beitrag von Ausländern und künftiger Zuwanderung zum deutschen Staatshaushalt, Erişim tarihi: 05.06.2018 https://www.bertelsmannstiftung.de/fileadmin/files/Projekte/28_Einwanderung_und Vielfalt/Bonin_Beitrag_Zuwanderung_zum_dt_Staatshaushalt_141204_nm.pdf

Migrantenunternehmen sind Jobmotor für Deutschland, Erişim tarihi: 05.04.2018 https://www.bertelsmannstiftung.de/de/themen/aktuellemeldungen/2016/august/ migrantenunternehmen-sind-jobmotor-fuer-deutschland/

NSU davası ombudsmanı John: Cinayetlere ilişkin birçok şey hala aydınlatılmadı , Erişim tarihi: 04.11.2017

https://www.aa.com.tr/tr/dunya/nsu-davasi-ombudsmani-john-cinayetlere-iliskinbircok-sey-hala-aydinlatilmadi/874471

İşte 2050〉de Almanya>yı bekleyen büyük tehlike, Erişim tarihi: 06.07.2018

http://www.hurriyet.com.tr/avrupa/iste-2050de-almanyayi-bekleyen-buyuktehlike-27379786

Brauchen wir wirklich mehr Kinder? , Erişim tarihi: 03.07.2017

https://www.stern.de/politik/deutschland/demografischer-wandel--brauchen-wirwirklich-mehr-kinder--7357454.html 
Besser Leben im Alter, Erişim Tarihi : 02.06.2017

https://www.zeit.de/2012/41/Demografie-Gipfel-Alter-Merkel

Migranten am Arbeitsmarkt in Deutschland, Erişim Tarihi: 04.08.2017

https://www.bamf.de/SharedDocs/Anlagen/DE/Publikationen/WorkingPapers/wp36migranten-am-arbeitsmarkt-in-deutschland.pdf?_blob=publicationFile 